\title{
EFEK KESEJAHTERAAN DARI KESEPAKATAN KEMITRAAN EKONOMI BILATERAL INDONESIA DAN AMERIKA SERIKAT TERKAIT PERDAGANGAN HASIL PERIKANAN
}

\author{
Tajerin, Agus Heri Purnomo dan Sastrawidjaja ${ }^{1}$ \\ ${ }^{1}$ Peneliti pada Balai Besar Riset Sosial Ekonomi Kelautan dan Perikanan \\ JI. KS Tubun Petamburan VI Jakarta 10260. \\ Telp. (021)53650162, Fax. (021)53650159 \\ Diterima 10 Maret 2010 - Disetujui 19 April 2010
}

\begin{abstract}
ABSTRAK
Momentum liberalisasi perdagangan akhir-akhir ini semakin menguat, sehingga mendorong Indonesia melakukan kesepakatan kemitraan ekonomi bilateral dengan negara mitra dagangnya seperti Amerika Serikat. Penelitian mengenai aspek kesejahteraan (surplus konsumen, surplus produsen dan surplus agregat) dari kesepakatan kemitraan ekonomi bilateral antara Indonesia dengan Amerika Serikat (Indonesian and United States of American Economic Partnership Agreement / IUSEPA) terkait dengan perdagangan hasil perikanan dilakukan pada tahun 2009. Data yang digunakan bersumber dari basis set data terintegrasi dari tiga database perdagangan dunia yang dimiliki WTO, TRAINS-UNCTAD dan UNSDCOMTRADE melalui penggunaan software WITS yang dikembangkan World Bank. Analisis dilakukan dengan pendekatan "SMART Model" dengan bantuan Software WITS. Hasil penelitian menunjukkan bahwa IUSEPA memberikan efek positif terhadap kesejahtaraan berupa surplus konsumen, surplus produsen dan surplus agregat. Besaran efek surplus produsen baru terlihat efeknya pada pemotongan tarif impor perikanan sebesar $80 \%$ dan $100 \%$, masing-masing sebesar US\$ 40,437 ribu dan sebesar US\$704,162 ribu. Demikian pula dengan efek surplus agregat, pada pemotongan tarif impor perikanan tersebut masingmasing memberikan efek total kesejahteraan sebesar US $\$ 28,033$ ribu dan sebesar US $\$ 234.748$ ribu. Dari perspektif sektoral, khususnya terkait dengan perdagangan hasil perikanan dalam kerangka IUSEPA, Indonesia perlu mengusulkan pemotongan tarif impor $80-100 \%$ atau pemberlakuan tarif impor $0-7 \%$ kepada pihak Amerika Serikat.
\end{abstract}

Kata Kunci: perdagangan bilateral, perikanan, efek kesejahteraan, WITS

\section{Abstract : Welfare Effect of Indonesia and United States of America Economic Bilateral Partnership Agreement Related with Fishery Trade. By: Tajerin, Agus Heri Purnomo and Sastrawidjaja.}

The intensified momentum of trade liberalization requires Indonesia to develop bilateral economic partnership agreement with its trading partners such with the United States. This research is an evaluation welfare aspects (consumer surplus, producer surplus and the aggregate surplus) of fishery products from bilateral economic partnership agreement between Indonesia and the United States of America (Indonesian and United States of American Economic Partnership Agreement /IUSEPA) in 2009. This research use integrated set database from three world trade databases (WTO, TRANS-UNCTAD and UNSD COMTRADE) with applying WITS software developed by the World Bank. It applied Smart Model approach using WITS software for analysis. The results of this research showed that IUSEPA has a positive effect on welfare in the form of consumer, producer and the aggregate surplus. Reducing import tariff by 80 and 100 per cent provided significant effect on producer surplus by US\$ 40,437 and US\$704,162 respectively. Similarly, the reduction resulted aggregate surplus and welfare effect by US\$28,033 and US\$234.748 respectively. From the sectoral perspective, Indonesia need to negotiate reduction tariff for fishery product up 80-100 per cent or put the import tariff into effect 0-7 per cent for United States under the IUSEPA framework.

Keywords: bilateral trade, fishery, welfare effect, WITS 


\section{PENDAHULUAN}

Momentum liberalisasi perdagangan untuk Indonesia, akhir-akhir ini bertambah kuat dan menyebabkan perdebatan pro dan kontra yang tampaknya belum akan segera berakhir. Kuatnya momentum tersebut diantaranya karena berkaitan erat dengan kisah sukses ekonomi China yang membuka diri terhadap ekonomi (perdagangan) dunia sejak akhir tahun 1970-an, dan bergabung dalam kerjasama liberalisasi perdagangan multilateral WTO pada tahun 2001, serta aktif dalam sejumlah kerjasama liberalisasi perdagangan bilateral dan regional. Di sisi lain bersama anggota WTO lainnya, Indonesia terikat dalam bentuk kerjasama liberalisasi perdagangan dalam tataran multilateral. Namun upaya liberalisasi perdagangan di bawah payung WTO tersebut hingga kini berjalan lamban (Setiawati dan Amier, 2004).

Sebagai perkembangan reaksi atas perkembangan lambannya liberalisasi perdagangan di bawah WTO tersebut, Indonesia dan banyak negara lainnya terdorong untuk melakukan kerjasama liberalisasi perdagangan secara bilateral. Beberapa tahun terakhir kerjasama tersebut bermunculan seperti "jamur di musim hujan". Isu kritis ini sekarang adalah apakah kerjasama perdagangan bilateral akan menjadi penghambat atau justru sebaliknya pendorong bagi terciptanya perdagangan bebas dunia seperti yang dicita-citakan dari pembentukan WTO.

Melalui bentuk kerjasama liberalisasi perdagangan bilateral, rejim Free Trade Agreements (FTAs) menghendaki adanya sifat preferential bagi beberapa negara yang menjadi mitra perdagangan. Artinya, tidak setiap negara memiliki akses yang sama terhadap perdagangan di suatu negara. Logika semacam ini kemudian membuat negara berlomba melakukan FTAs, karena khawatir negaranya tidak mendapatkan akses pasar ke negara mitra dagangnya ketika mitra dagang tersebut melakukan FTAs dengan negaralain. Ketakutan itu meluas, dan akhirnya terjadi semacam silang "singkarut" dalam struktur perdagangan internasional, karena setiap negara tidak mau kalah bersaing dalam memperebutkan akses pasar ke negara lain. Bhagwati (1991) menyebut hal ini dengan fenomena "spaghetty bowl" atau spaghetty yang saling menjulur tidak beraturan dan tumpang tindih dalam sebuah mangkuk yang diumpamakan sebagai dunia.

Dalam posisi bilateral, negosiasi menjadi lebih fleksibel karena mempertimbangkan aspek-aspek yang ada di kedua negara yang melakukan kesepakatan. Menurut Baldwin (1995) karena fleksibilitas tersebut, biasanya FTAs mempunyai cakupan yang lebih luas daripada perdagangan bebas multilateral yang lebih menonjolkan aspek nondiscriminatory-nya. Dengan adanya rejim perdagangan bilateral ini, terlihat bahwa proses liberalisasi perdagangan kini makin berjalan cepat. Proses perundingannya pun lebih cepat dibandingkan dengan proses sebuah negara masuk ke dalam WTO. Artinya, dalam hal mengubah kebijakan nasional, FTAs ini dapat menjadi cepat dan efektif dibandingkan cara-cara perundingan multilateral yang banyak terdapat konflik kepentingan antar negara; bukan saja antara negara maju dan negara berkembang, namun juga antara sesama negara maju atau sesama negara berkembang.

Setelah dilakukan kesepakatan kemitraan ekonomi bilateral antara Indonesia dengan Jepang, dalam kurun beberapa waktu lalu telah dirintis melalui negosiasi-negosiasi untuk dilakukan kemungkinan hal yang sama dengan Amerika Serikat. Diharapkan dalam tempo yang tidak lama lagi, kesepakatan kemitraan ekonomi bilateral antara Indonesia dengan Amerika (Indonesia - United State of America Economic Partnership Agreement I IUSEPA) tersebut akan segera teralisasi. IUSEPA sebagai salah satu cara mengisi kekurangan negosiasi di WTO, khususnya dalam memperkuat kemitraan ekonomi yang lebih luas dari WTO sehingga Amerika Serikat 
dapat mengembangkan hubungan ekonomi luar negerinya dengan Indonesia.

Kebanyakan analis yakin bahwa sifat preferential bagi negara-negara yang melakukan kesepakatan ekonomi bilateral seperti FTAs (seperti yang akan dilakukan antara Amerika Serikat dan Indonesia), secara teoritis memberikan efek positif bagi kedua negara yang melakukan kesepakatan ekonomi bilateral (Krugman, 1991). Efek positif tersebut tentunya juga terkait dengan perdagangan komoditas dan produk perikanan antara Indonesia dan Amerika Serikat.

Pada akhirnya, esensi sebenarnya dari IUSEPA tersebut adalah tercapainya peningkatan kesejahteraan manusia melalui optimalisasi alokasi sumberdaya. Apakah rencana IUSEPA akan memberikan dampak positif bagi kegiatan perekonomian, khususnya terkait dengan perdagangan perikanan? Untuk itu, penelitian ini dilakukan dengan tujuan untuk mengestimasi efek kesejahteraan dari IUSEPA terkait dengan perdagangan perikanan, khususnya dilihat dari perubahan pada surplus konsumen, surplus produsen dan surplus agregat.

\section{METODOLOGI}

\section{Landasan Teoritis}

Sebagai bagian integral dalam kesepakatan-kesepakatan WTO, kerjasama perdagangan baik multilateral, regional maupun bilateral akan berimplikasi pada terjadinya kondisi pengalihan perdagangan (Trade Diversion / TD) dan penciptaan perdagangan (Trade Creation / TC) (Viner, 1990). Akibat dari terjadinya TD dan TC (sebagai konsekuensi diterapkannya instrumen-instrumen kebijakan perdagangan dalam kerjasama perdagangan tersebut) akan menimbulkan efek kesejahteraan dari proses perdagangan secara keseluruhan. Efek kesejahteraan tersebut akan terlihat dari besaran nilai perubahan surplus konsumen dan surplus produsen. Istilah surplus konsumen (consumer surplus) pertama kali diperkenalkan oleh Dupuit pada 1952 yang didefinisikan sebagai pengukuran kesejahteraan di tingkat konsumen, yang diukur berdasarkan selisih keinginan membayar (willingness to pay - WTP) dari seseorang dengan apa yang sebenarnya ingin dia bayarkan (Brent, 1997). Consumer surplus didefinisikan sebagai perbedaan antara harga sebuah barang dimana konsumen bersedia membayar dan harga sebenarnya yang dibayar oleh konsumen tersebut. Dalam kaitan ini, total consumer surplus direpresentasikan oleh area KLM di Gambar 1a. Sementara itu, producer surplus merupakan perbedaan antara harga jual sebuah barang yang sebenarnya diperoleh oleh perusahaan dengan harga jual (minimal) yang bersedia diterima oleh perusahan tersebut. Dari Gambar 1b, area LMN merupakan total producer surplus.

\section{(a) Pengalihan Perdagangan dan Efek Kesejahteraannya}

Trade diversion merupakan dampak negatif dari impor barang yang harganya relatif lebih murah dari negara bukan anggota FTA, sehingga diganti dengan impor yang harganya relatif lebih mahal dari negara anggota. Hal ini terjadi karena adanya preferential tarif yang diberikan kepada sesama negara anggota. Dengan demikian, trade diversion dapat mengurangi manfaat yang seharusnya diperoleh dari spesialisasi perdagangan internasional sebagai akibat adanya pergeseran produksi dari negara (bukan anggota) yang lebih efisien ke negara (anggota) yang kurang efisien.

Gambar 2. menunjukkan kurva permintaan dan penawaran untuk negara $A$ yang terjadi akibat transaksi perdagangannya dengan Negara $B$ dan $C$. $P^{B}$ dan $P^{C}$ menggambarkan harga pasokan barang dalam perdagangan bebas dari negara $B$ dan negara $C$. Perlu dicatat bahwa negara $C$ diasumsikan mampu untuk memasok produk pada tingkat harga yang lebih rendah 


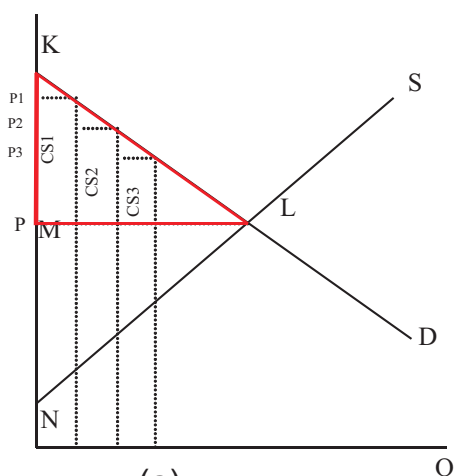

(a)

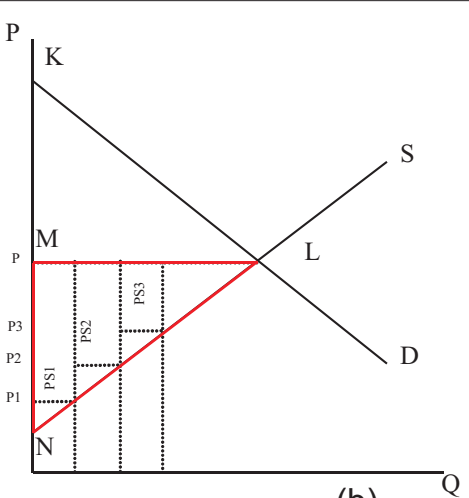

(b)

\section{Gambar 1. Surplus Konsumen dan Surplus Produsen}

Figure 1. Consumer Surplus and Producer Surplus

Sumber: diadaptasi dari Suranovic (1997) dalam Pratomo (2007)/

Source: adopted from Suranovic (1997) in Pratomo (2007)

dibandingkan dengan negara $B$ untuk barang yang sama di negara $A$. Di samping itu diasumsikan pula bahwa negara $A$ memiliki tarif spesifik $t B=t C=t^{*} \operatorname{dimana}$ negara $A$ mengimpor dari $B$ dan $C$.

Tarif dari negara $A$ tersebut mengakibatkan meningkatnya harga pasokan di dalam negeri $A$ dari $\mathrm{P}_{c}^{t}$ (harga barang negara C setelah ada tarif dari negara $A$ ), dimana tarif adalah $t^{*}=P_{B}^{T}-P^{B}=P_{C}^{T}-P^{C}$.
Sejak diberlakukannya tarif oleh negara $A$ tersebut, harga barang yang ditawarkan negara $C$ lebih murah, maka negara $A$ akan mengimpor barangnya dari negara $C$ dan tidak akan melakukan perdagangan dengan negara $B$. Impor ditunjukkan oleh daerah dengan jarak antara $D^{1}-S^{1}$. Sedangkan penerimaan tarif awal bagi negara $A$ ditunjukan oleh area $(c+$ e), dimana tingkat tarif dikalikan dengan kuantitas barang yang diimpor.

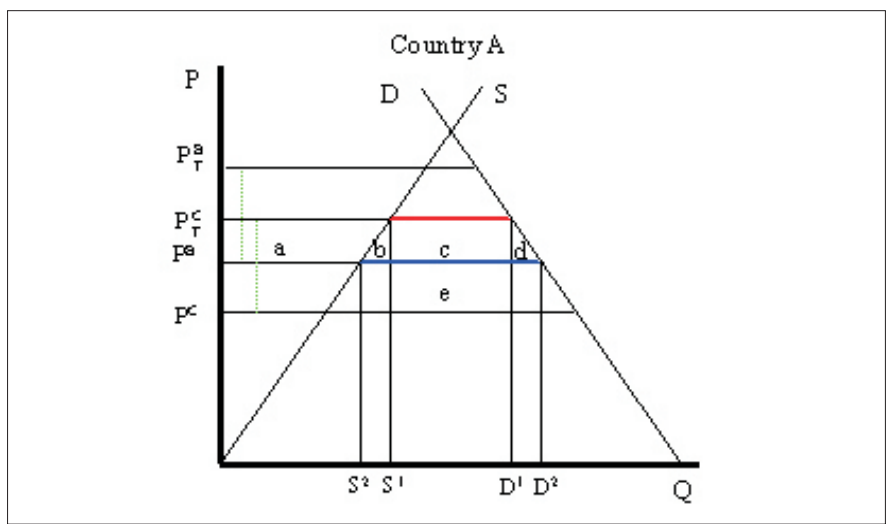

Gambar 2. Kurva Permintaan dan Penawaran dalam Pengalihan Perdagangan Figure 2. Curve of Demand and Supply in Trade Diversion

Sumber: diadaptasi dari Suranovic (1997) dalam Pratomo (2007)

Source: adopted from Suranovic (1997) in Pratomo (2007) 
Selanjutnya, asumsikan negara $A$ dan $B$ membentuk FTA, dan $A$ menghapuskan tarif impornya dari negara $B$. Sekarang tarif bagi negara $B$ atau $t B=0$ tetapi tarif bagi negara $C$ atau $t C$ sama seperti pada $t^{*}$. Harga barang dalam negeri dari Negara $B$ dan $C$ sekarang menjadi $\mathrm{P}^{\mathrm{B}}$ dan $\mathrm{P}_{c}^{t}$ Sejak $\mathrm{P}^{\mathrm{B}}$ lebih rendah dari $\mathrm{P}_{c}^{t}$ negara $A$ akan mengimpor semua barang dari negara $B$ setelah adanya FTA dan tidak akan mengimpor dari Negara $C$. Pada harga dalam negeri yang lebih rendah, $P^{\beta}$, impor akan meningkat dari $D^{2}$ ke $S^{2}$. Juga sejak adanya free trade, harga di Negara $C$ lebih rendah dibandingkan harga di Negara $B$, hal tersebut dapat dikatakan perdagangan dialihkan dari pemasok yang lebih efisien ke pemasok yang lebih tidak efisien. Efek kesejahteraan digambarkan dalam Tabel 1.

\section{(b) Penciptaan Perdagangan dan Efek Kesejahteraannya}

Secara umum, penciptaan perdagangan memiliki arti bahwa area perdagangan bebas menciptakan perdagangan (trade creation) yang tidak akan ada sebelumnya. Sebagai akibatnya, pasokan terjadi dari produsen suatu produk yang lebih efisien. Dalam semua kasus, penciptaan perdagangan akan meningkatkan kesejahteraan nasional suatu negara. Seperti yang dijelaskan dalam diagram pada Gambar 3.

Gambar 3 menunjukkan kurva permintaan dan penawaran Negara $A$ yang terjadi akibat dilakukannya transaksi perdagangan dengan negara $B$ dan negara $C$. Dalam hal ini negara $B$ dan $C$ bertindak sebagai pemasok barang ke negara $A$. $\mathrm{P}^{\mathrm{B}}$ dan

Tabel 1. Efek Kesejahteraan dari Free Trade dalam Membentuk Pengalihan Perdagangan Table 1. Welfare Effect from Free Trade in Form Trade Diversion

\section{Jenis Efek Kesejahteraan/ Kinds of Welfare Effect}

Surplus Konsumen/ Consumer Surplus

Surplus Produsen/ Producer Surplus

Penerimaan Pemerintah/ Custom Revenue

Kesejahteraan Nasional/ National Welfare

\section{Negara/ Country A}

$$
\begin{array}{r}
+(a+b+c+d) \\
-a \\
-(a)+e) \\
+(b+d)-e
\end{array}
$$

Sumber: Suranovic (1997) dalam Pratomo (2007)/ Source: Suranovic (1997) in Pratomo (2007)

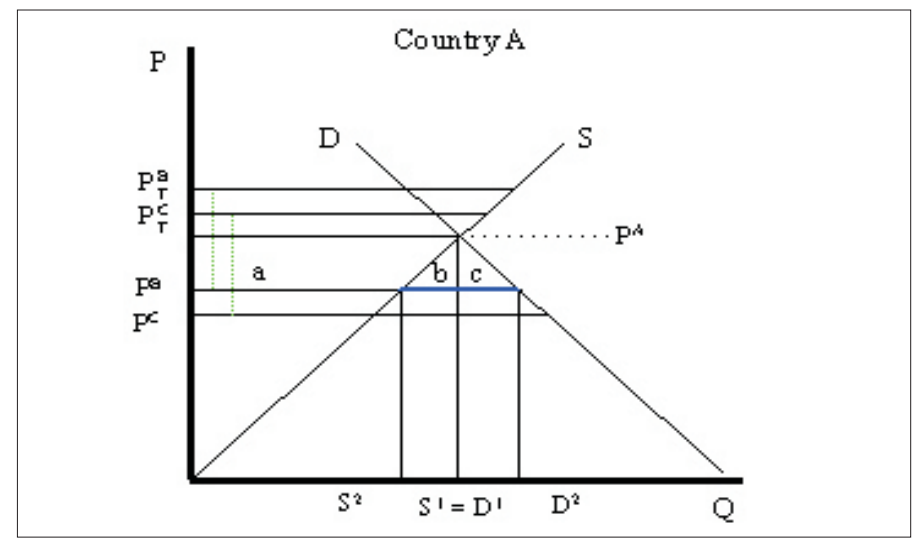

Gambar 3. Kurva Permintaan dan Penawaran dalam Penciptaan Perdagangan Figure 3. Curve of Demand and Supply in Trade Creation

Sumber: diadaptasi dari Suranovic (1997) dalam Pratomo (2007)

Source: adopted from Suranovic (1997) in Pratomo (2007) 
$\mathrm{P}^{\mathrm{C}}$ menggambarkan harga pasokan barang dalam perdagangan bebas dari negara $B$ dan negara $C$. Sedangkan negara $C$ diasumsikan mampu untuk memasok produk pada tingkat harga yang lebih rendah dibandingkan dengan negara $B$. Perlu dicatat bahwa negara $B$ harus memiliki tarif untuk produk yang diimpor dari negara $C$, pasar pada negara $B$ akan dipasok oleh $C$. Sama halnya dengan pengalihan perdagangan, pada penciptaan perdagangan diasumsikan bahwa $A$ memiliki tarif spesifik $t B=t C=t^{*}$ dimana negara $A$ mengimpor dari negara $B$ dan $C$. Tarif mengakibatkan meningkatnya harga dalam negeri dari $P_{\mathrm{b}}^{t}$ ke $P_{c}^{t}$ Besarnya tarif adalah:

$$
\mathrm{t}^{\star}=P_{B}^{T}-\mathrm{P}^{\mathrm{B}}=P_{C}^{T}-\mathrm{P}^{\mathrm{C}} \text {. }
$$

Sejak diberlakukannya tarif, harga keseimbangan awal di negara $A$ yang ditunjukan oleh $\mathrm{P}^{A}$ pada diagram menjadi lebih murah dibandingkan dengan harga tarif $P_{\mathrm{b}}^{t}$ ke $P_{c}^{t}$ dalam hal ini produk tidak akan diimpor, kecuali jika negara $A$ akan memasok permintaan dalam negerinya pada $S^{1}=D^{1}$.

Selanjutnya, asumsikan negara $A$ dan $B$ membentuk FTA dan Negara $A$ menghapuskan tarif impornya dari negara $B$. Sekarang $t B=0$ tetapi $t C$ sama seperti pada $t^{*}$. Harga barang dalam negeri dari Negara $B$ dan $C$ menjadi $P^{B}$ dan $P_{c}^{t}$ Sejak $P^{B}<P^{A}$, Negara A akan mengimpor semua produk dari Negara $B$ setelah adanya FTA. Pada harga dalam negeri yang lebih rendah, $P^{\beta}$, impor akan meningkat dari $D^{2}$ ke $S^{2}$. Sejak perdagangan terjadi dengan FTA, dan tidak akan terjadi sebelumnya, hal tersebut bisa dikatakan perdagangan diciptakan. Efek kesejahteraan digambarkan dalam Tabel 2 .

\section{Jenis dan Sumber Data}

Penelitian ini dilakukan dengan menggunakan data sekunder dari sumber Trade Analysis and Information System (TRAINS) UNCTAD, UNSD COMTRADE, dan WTO yang merupakan database terintegrasi WTO melalui penggunaan software WITS (sebagai sumber data) yang diperoleh melalui website: http://wits.worldbank.org/website (Bacchetta and Jammes, 2004).

\section{Metode Analisis Data}

Analisis aspek kesejahteraan (surplus konsumen, surplus produsen dan surplus agregat) dari IUSEPA terkait perdagangan perikanan Indonesia dalam penelitian ini dilakukan dengan menggunakan framework keseimbangan parsial (partial equilibrium). Secara umum terdapat dua model dasar keseimbangan parsial yang dapat dipergunakan untuk menganalisis kedua efek tersebut. Model pertama berlandaskan asumsi komoditas homogen, sedangkan model kedua dibangun berdasarkan asumsi "Armington" (Armington, 1969 dalam Christos et al,, 2004), dimana Armington meneliti sifat dari fungsi permintaan impor ketika barang-barang impor dan barang produksi domestik dipergunakan sebagai barang substitusi tidak sempurna. Metode yang dipergunakan dalam penelitian

\section{Tabel 2. Efek Kesejahteraan dari Free Trade dalam Membentuk Penciptaan Perdagangan} Table 2. Welfare Effect from Free Trade in Form Trade Creation

\section{Jenis Efek Kesejahteraan/ Kinds of Welfare Effect}

Surplus Konsumen/ Consumer Surplus

Surplus Produsen/ Producer Surplus

Penerimaan Pemerintah/ Custom Revenue

Kesejahteraan Nasional/ National Welfare

\section{Negara A/Country A}

$$
\begin{array}{r}
+(a+b+c) \\
-a \\
0 \\
+(b+c)
\end{array}
$$


ini termasuk ke dalam kategori yang kedua, yang diantaranya adalah dengan pendekatan SMART Model (Grobmann and Busse (2004).

Dalam pelaksanaannya, penelitian ini dilakukan dengan menggunakan pendekatan analisis SMART Model. Model ini pada dasarnya merupakan pengembangan lebih lanjut dari "Model Produk Terdiferensiasi", yang dikembangkan oleh Verdoorn tahun 1960 (Großmann and Busse, 2004). Pada awalnya model ini diformulasi untuk tujuan analisis lebih dari sisi kepentingan negara konsumen (buyer) dari komoditas-komoditas atau produk-produk yang diimpor dari negara produsen. Namun dalam perkembangan selanjutnya, model tersebut disempurnakan oleh UNCTAD dan the World Bank sejak tahun 1980an terutama untuk menilai dampak dari GATT rounds, sehingga dapat digunakan untuk analisis, tidak saja untuk kepentingan negara konsumen tetapi juga negara produsen yang melakukan kesepakatan perdagangan (ekonomi). Model ini dikenal dengan dikenal dengan sebutan "SMART Model".

SMART Model tersebut terdapat dalam WITS (World Integrated Trade Solutions) software, yang diantaranya dapat digunakan untuk mengevaluasi dan melihat efek dari perubahan kebijakan perdagangan (dalam ukuran tarif) dalam beberapa variabel-variabel yang terkait dengan kerjasama bilateral, yaitu: Efek Trade Creation (TC), Efek Trade Diversion (TD), dan Agregasi TC dan TD. Selain itu, SMART Model juga dapat menunjukkan variabel-variabel yang berkaitan dengan dampak dari kerjasama bilateral, seperti perubahan dalam Surplus Konsumen, Produsen dan Nasional.

SMART Model dalam WITS memiliki 3 jenis elastisitas: (1) Supply elasticities bernilai 0,99 (atau sangat dekat dengan satu) yang berarti bahwa peningkatan permintaan untuk barang tertentu akan selalu dicocokkan oleh produsen dan eksportir dari barang tersebut, tanpa adanya dampak pada harga barang tersebut; (2) Import substitution elasticities barang yang sama dari negara yang berbeda imperfectly substitutable. Dalam SMART Model, import substitution elasticity bernilai 1,5 untuk setiap barang; (3) Import demand elasticity mengukur respon permintaan dalam beralih ke harga import. Dalam SMART Model, import demand elasticity berdasarkan pada "price elasticities in international trade". Asumsi penting lainnya dari model ini adalah perfect competition, dimana dalam pemotongan tarif secara penuh dicerminkan dalam harga yang dibayarkan konsumen.

\section{Pemilihan Skenario Simulasi}

Analisis aspek kesejahteraan dari IUSEPA terkait dengan perdagangan hasil perikanan, dalam penelitian ini dimasudkan sebagai analisis estimasi efek yang timbul akibat pemotongan tarif impor (tarif bea masuk). Untuk perlu disediakan beberapa "skenario pemotongan tarif" dengan variasi pemilihan yang representatif terhadap kemungkinan perubahan efek (dampak) yang akan terjadi kemudian.

Penentuan skenario pemotongan tarif impor perikanan dalam hal ini dilakukan berdasarkan simulasi pendahuluan mengenai tingkat kepekaan dari trade effect, yang dalam hal ini mewakili indikator nilai perdagangan total (Total Trade)" yang dilakukan berdasarkan analisis program WITS. Indikator perdagangan total tersebut merupakan indikator penting dan menentukan derajat efek yang mungkin timbul akibat perubahan tarif dalam transaksi perdagangan bilateral (Bacchetta and Jammes, 2004).

Dengan mempertimbangkan variasi pemilihan yang representatif untuk "skenario pemotongan tarif" terutama terhadap kemungkinan perubahan efek (dampak) yang akan terjadi kemudian, maka berdasarkan hasil simulasi pendahuluan tersebut dimungkinkan kita menggunakan lima skenario pemotongan tarif, yaitu sebesar $20 \%$, $40 \%, 60 \%, 80 \%$ dan $100 \%$ untuk keperluan analisis simulasi dalam penelitian ini. Masingmasing skenario simulasi tersebut dijelaskan pada Tabel 3. 


\section{Tabel 3. Simulasi pada Berbagai Skenario dengan Perlakuan Pemotongan Tarif Impor atau Bea Masuk (Impor) Perikanan yang digunakan dalam Analisis}

Table 3. Simulation for Every Scenario by Treatment of Import Tariff Cutting or Import Tax for Fisheries which is Used in Analysis

\begin{tabular}{|c|c|c|c|c|}
\hline \multirow[b]{2}{*}{$\begin{array}{c}\text { Skenario/ } \\
\text { Scenario-1: }\end{array}$} & \multicolumn{3}{|c|}{ SIMULASI/SIMULATIONS } & \multirow[b]{2}{*}{$\begin{array}{c}\text { Skenario/ } \\
\text { Scenario-5: }\end{array}$} \\
\hline & $\begin{array}{c}\text { Skenario/ } \\
\text { Scenario-2: }\end{array}$ & $\begin{array}{l}\text { Skenario/ } \\
\text { Scenario-3: }\end{array}$ & $\begin{array}{c}\text { Skenario/ } \\
\text { Scenario-4: }\end{array}$ & \\
\hline $\begin{array}{l}\text { IUSEPA merujuk } \\
\text { pada arahan WTO } \\
\text { "secara bertahap" } \\
\text { dengan } \\
\text { pemberlakukan tarif } \\
\text { bea masuk } \\
\text { perikanan } 28 \% \text { / } \\
\text { IUSEPA refers to } \\
\text { WTO direction "in } \\
\text { stages" with } \\
\text { conducted fisheries } \\
\text { import tax } 28 \% \text { *) }\end{array}$ & $\begin{array}{l}\text { IUSEPA merujuk } \\
\text { pada arahan WTO } \\
\text { "secara bertahap" } \\
\text { dengan } \\
\text { pemberlakukan } \\
\text { tarif bea masuk } \\
\text { perikanan } 21 \% / \\
\text { IUSEPA refers to } \\
\text { WTO direction "in } \\
\text { stages" with } \\
\text { conducted } \\
\text { fisheries import tax } \\
21 \% \text { *) }\end{array}$ & $\begin{array}{l}\text { IUSEPA merujuk } \\
\text { pada arahan WTO } \\
\text { "secara bertahap" } \\
\text { dengan } \\
\text { pemberlakukan tarif } \\
\text { bea masuk } \\
\text { perikanan } 14,0 \% / \\
\text { IUSEPA refers to } \\
\text { WTO direction "in } \\
\text { stages" with } \\
\text { conducted fisheries } \\
\text { import tax } 14 \% \text { *) }\end{array}$ & $\begin{array}{l}\text { IUSEPA merujuk } \\
\text { pada arahan } \\
\text { WTO"secara } \\
\text { bertahap" dengan } \\
\text { pemberlakukan tarif } \\
\text { bea masuk } \\
\text { perikanan } 7,0 \% / \\
\text { IUSEPA refers to } \\
\text { WTO direction "in } \\
\text { stages" with } \\
\text { conducted fisheries } \\
\text { import tax } 7 \% * \text { ") }\end{array}$ & $\begin{array}{l}\text { IUSEPA merujuk } \\
\text { pada arahan WTO } \\
\text { "secara penuh" } \\
\text { dengan } \\
\text { pemberlakukan } \\
\text { tarif bea masuk } \\
\text { perikanan 0\%/ } \\
\text { IUSEPA refers to } \\
\text { WTO direction "in } \\
\text { stages" with } \\
\text { conducted } \\
\text { fisheries import tax } \\
0 \% \text { *) }\end{array}$ \\
\hline Shock: & Shock: & Shock: & Shock: & Shock: \\
\hline $\begin{array}{l}\text { Pemotongan Tarif } \\
\text { Impor Perikanan } \\
20 \% \text { l Cutting on } \\
\text { Tariff of Fisheries } \\
\text { Import } 20 \%\end{array}$ & $\begin{array}{l}\text { Pemotongan } \\
\text { Tariff Impor } \\
\text { Perikanan } 40 \% / \\
\text { Cutting on Tariff } \\
\text { of Fisheries } \\
\text { Import } 40 \%\end{array}$ & $\begin{array}{l}\text { Pemotongan Tarif } \\
\text { Impor Perikanan } \\
60 \% \text { / Cutting on } \\
\text { Tariff of Fisheries } \\
\text { Import } 60 \%\end{array}$ & $\begin{array}{c}\text { Pemotongan Tarif } \\
\text { Impor Perikanan } \\
80 \% \text { / Cutting on } \\
\text { Tariff of Fisheries } \\
\text { Import } 80 \%\end{array}$ & $\begin{array}{l}\text { Pemotongan } \\
\text { Tarif Impor } \\
\text { Perikanan } 100 \% / \\
\text { Cutting on Tariff } \\
\text { of Fisheries } \\
\text { Import } 100 \%\end{array}$ \\
\hline
\end{tabular}

Keterangan/ Remaks:

*) Diperoleh dari hasil penyetaraan kisaran pemberlakukan tarif bea masuk (TBM) perikanan Indonesia ke Amerika Serikat, yaitu sebesar $0-35 \%$ (Tabel 1) dengan kisaran besaran pemotongan tarif impor (PTI) perikanan sebesar 0 $100 \%$. Dimana TBM sebesar $0 \%$ setara dengan PTI sebesar $100 \%$, dan TBM sebesar $35 \%$ setara dengan PTI sebesar $0 \% /$ Getted from equivalency produce on interval conducted fisheries import tax (PTI) from Indonesian to United States of American 0-35\% (Table 1) with interval fisheries import tarif cutting (TBM) $0-100 \%$. Where TBM 0\% equivalent to PTI 100\%, and TBM $35 \%$ equivalent to PTI $0 \%$.

\section{HASIL DAN PEMBAHASAN}

\section{Efek Surplus Konsumen dari IUSEPA}

Surplus konsumen pada kenyataannya tidak berdiri sendiri tetapi merupakan sebuah akibat (dampak) dari suatu keadaan lainnya. Sebagaimana terlihat pada Tabel 4 dan Gambar 4, tampak bahwa nilai surplus konsumen yang diperoleh pihak Amerika Serikat memiliki hubungan dengan perubahan nilai impor dan penerimaan tarif impornya. Tampak bahwa perningkatan impor perikanan oleh pihak Amerika Serikat akan mendorong peningkatan surplus konsumennya; di sisi lain peningkatan impor tersebut berimplikasi terhadap peningkatan penerimaan tarif yang pada gilirannnya juga memberikan kontribusi peningkatan efek surplus konsumennya.

Untuk kasus perdagangan komoditas dan produk perikanan dengan Indonesia, besaran surplus konsumen tersebut baru terlihat pada simulasi dengan skenario- 5 , yaitu pemotongan tarif sebesar $100 \%$ dengan nilai peningkatan surplus konsumen sebesar US\$ 234,748 ribu. Sementara pada simulasi dengan skenario lainnya (skenario-1, 


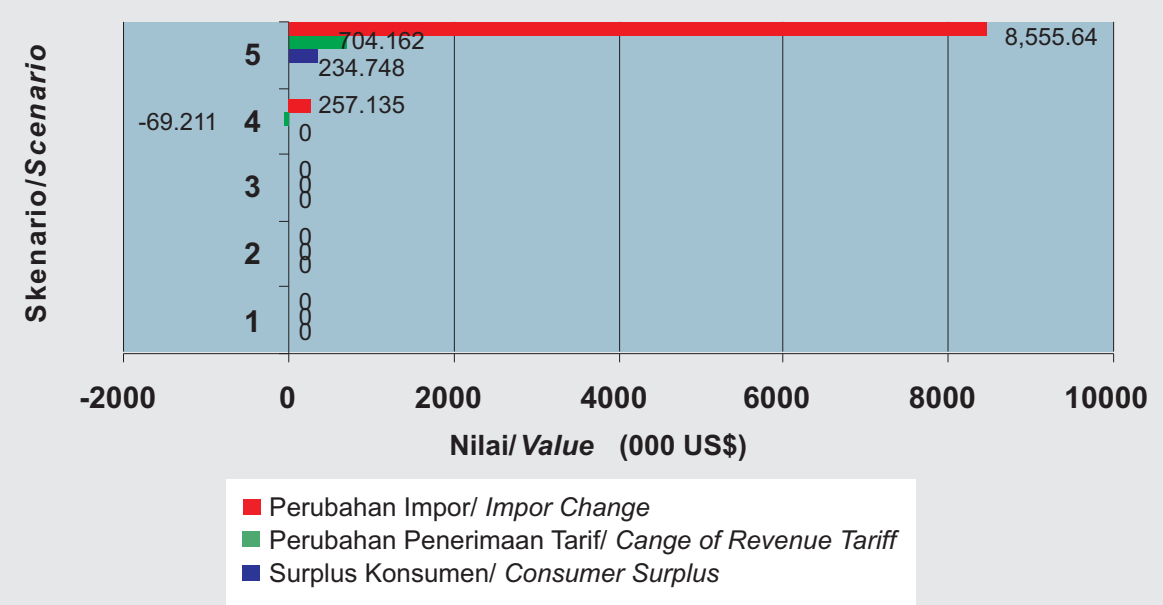

\section{Gambar 4. Efek IUSEPA pada Perubahan Impor, Penerimaan Tarif dan Surplus Konsumen Menurut Skenario Pemotongan Tarif Impor, 2009}

Figure 4. IUSEPA Effect on Import Chnage, Tariff revenue and Consumers Surplus by Scenarios of Import Tariff Cutting, 2009

skenario-2, skenario-3, dan skenario-4) dengan pemotoongan tarif dari sebesar $20 \%$, $40 \% \quad 60 \%$ dan $80 \%$ belum memberikan pengaruh terhadap peningkatan surplus konsumen tersebut (efek surplus konsumen yang terjadi sebesar nol) (lihat Tabel 4 dan Gambar 5).
Selanjutnya bila efek surplus konsumen tersebut dilihat menurut jenis komoditas atau produk perikanan yang diperdagangkan, ternyata peningkatan surplus konsumen sebesar US\$234,748 ribu dari hasil simulasi dengan skenario-5 tersebut ternyata didominasi oleh nilai efek surplus konsumen

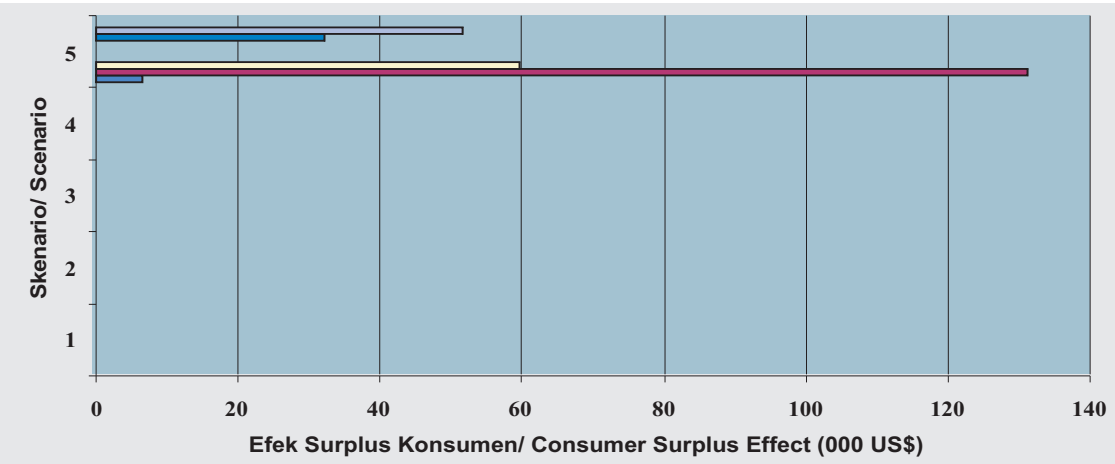

- Komoditas tuna/ Tuna commodity

Komoditas ikan lainnya/ Another fish commodity

- Produk minyak ikan/ Fish oil product

Produk rumput laut/ Seaweed product

- Produk tuna/ Tuna product

- Produk udang/ Shrimp product

- Produk ikan lainnya/ Another fish product

- Mutiara/ Pear

Gambar 5. Efek Surplus Konsumen menurut Komoditas dan Produk Perikanan dari Skenario Pemotongan Tarif Impor, 2009

Figure 5. Consumers Surplus Effect by Fisheries Commodity and Product from Scenarios of Import Tariff Cutting, 2009 


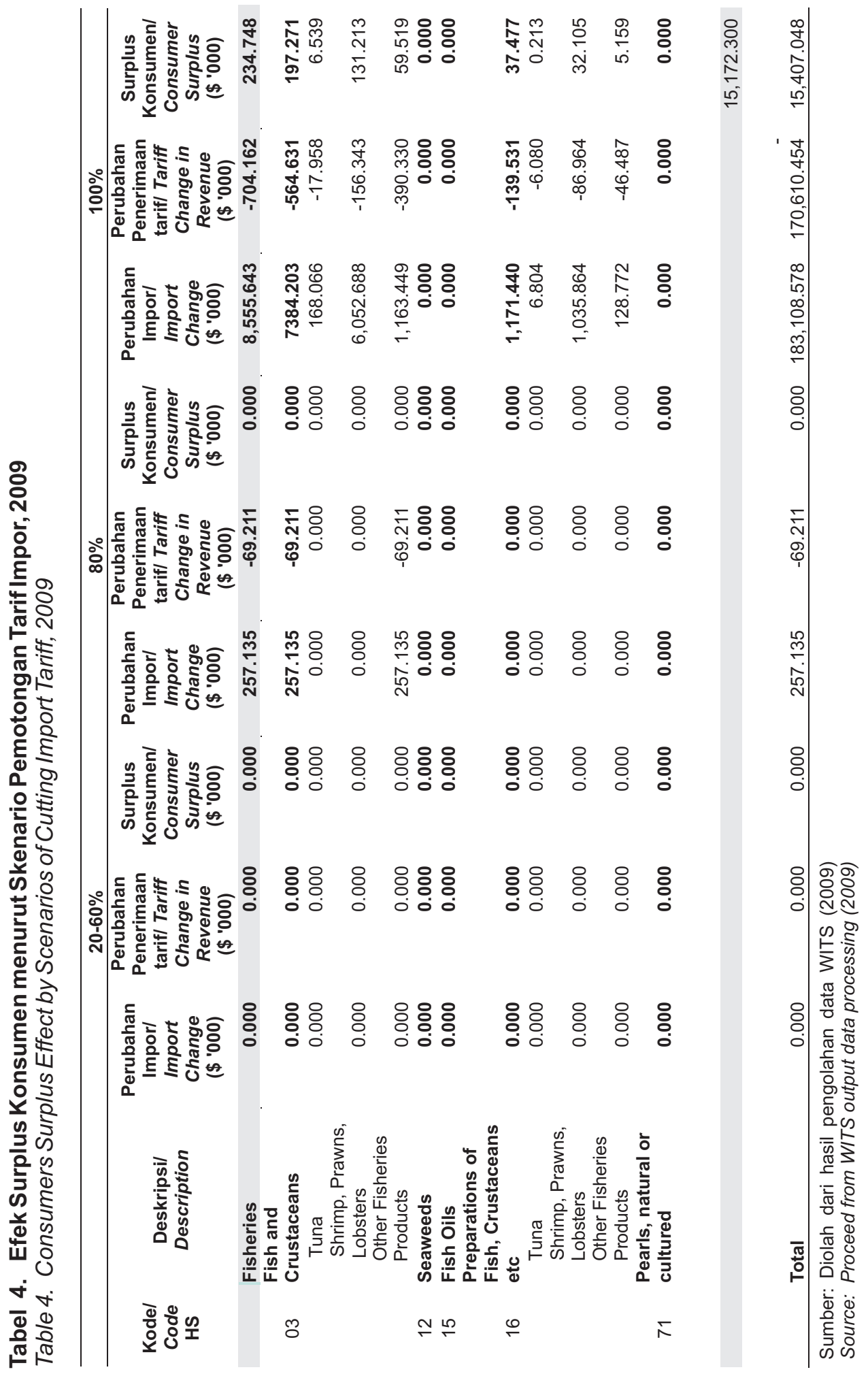


yang diperoleh dari perdagangan komoditas udang dengan peningkatan (efek) surplus konsumen sebesar US\$131,213 ribu, dan perdagangan produk olahan udang dengan peningkatan (efek) surplus konsumen sebesar US\$32,105 ribu. Kemudian baru disusul oleh efek surplus konsumen yang diberikan dari perdagangan komoditas dan produk olahan tuna, masing-masing sebesar US\$ 6,539 ribu dan US\$0, 213.

Mengingat bahwa analisis berbasiskan WITS ini dilakukan dengan pendekatan partial equilibrium, maka besaran nilai perubahan (efek) surplus produsen secara langsung tidak disajikan dari output hasil olahan dengan menggunakan WITS tersebut. Namun demikian hal tersebut dapat diatasi dengan cara melakuan penghitungan lebih lanjut berdasarkan besaran nilai (perubahan) efek surplus konsumen yang dihasilkan dari simulasi pada berbagai skeneraio pemotongan tarif (skenario-1 hingga skenario5).
Secara teoritis, menurut Suranovic dalam Pratomo (2004), penghitungan nilai kesejahteraan, di dalam besaran nilai surplus konsumen mencakup besaran nilai surplus produsen dimana proporsinya ditentukan oleh total perdagangan yang meliputi nilai pengalihan perdagangan dan nilai penciptaan perdagangan yang dilakukan (lihat Gambar 1 dan Gambar 2). Namun demikian secara implisit memberikan penjelasan lebih lanjut seperti tertuang dalam Tabel 5 bahwa efek surplus produsen dapat dihitung dengan penghitungan matematis sederhana, yaitu: "efek surplus produsen sama dengan efek surplus konsumen dikurangi efek penerimaan tarif pemerintah dan efek kesejahteraan". Teknik penghitungan efek surplus produsen ini dapat dilakukan dengan mudah, karena dari hasil pengolahan data berbasis WITS diperoleh nilai besaran efek surplus konsumen, efek penerimaan tarif impor dan welfare efect itu sendiri (lihat Tabel 1 dan Tabel 2).

\section{Tabel 5. Efek Surplus Produsen dari IUSEPA menurut Skenario Pemotongan Tarif Impor, 2009}

Table 5. Producers Surplus Effect from IUSEPA by Scenarios of Impor Tariff Cutting, 2009

\begin{tabular}{|c|c|c|c|c|c|}
\hline & & ek (Perubah & an)/ Effect (C & anges) (000 & \\
\hline & $\begin{array}{c}\text { Skenario 1/ } \\
\text { Scenario- } \\
1\end{array}$ & $\begin{array}{c}\text { Skenario 2l } \\
\text { Scenario- } \\
2\end{array}$ & $\begin{array}{c}\text { Skenario 3/ } \\
\text { Scenario- } \\
3\end{array}$ & $\begin{array}{l}\text { Skenario 4/ } \\
\text { Scenario-4 }\end{array}$ & $\begin{array}{l}\text { Skenario 5/ } \\
\text { Scenario -5 }\end{array}$ \\
\hline $\begin{array}{l}\text { Surplus Konsumen/ } \\
\text { Consumers Surplus }\end{array}$ & 0 & 0 & 0 & 0 & 234,748 \\
\hline $\begin{array}{l}\text { Penerimaan Tarif } \\
\text { Impor Pemerintah/ } \\
\text { Gevernment } \\
\text { Revenue from } \\
\text { Import Tariss }\end{array}$ & 0 & 0 & 0 & $-69,211$ & $-704,162$ \\
\hline $\begin{array}{l}\text { Kesejahteraan } \\
\text { National/ National } \\
\text { Welfare }\end{array}$ & 0 & 0 & 0 & 28,033 & 234,748 \\
\hline $\begin{array}{l}\text { Surplus } \\
\text { Produsen/ } \\
\text { Producers } \\
\text { Surplus }\end{array}$ & 0 & 0 & 0 & 40,437 & 704,162 \\
\hline
\end{tabular}


Selanjutnya mengingat bahwa Indonesia dalam kaitannya dengan IUSEPA lebih menempati posisi sebagai produsen hasil perikanan yang diperdagangkan (ekspor) ke pasar Amerika Serikat, maka surplus produsen dalam analisis adalah merupakan surplus produsen hasil perikanan di Indonesia. Di samping itu, karena keterbatasan dari hasil olahan WITS yang tidak menyajikan nilai surplus produsen, penghitungannya dapat dilakukan melalui pendekatan sebagaimana tertera dalam Tabel 2 di atas, yaitu mengikuti pola penghitungan efek kesejahteraan dari Free Trade dalam membentuk pengalihan perdagangan. Dengan formulasi ini, efek surplus produsen (agregat) dari IUSRPA terkait dengan perdagangan hasil perikanan dapat dihitung dengan hasil seperti tertera pada Tabel 5.

Dari Tabel 6 dan Gambar 6 dapat diketahui terdapat kecendrungan adanya peningkatan surplus produsen seiring dengan meningkatnya pemotongan tarif impor. Atau dengan kata lain terdapat hubungan yang positif antara perubahan tingkat pemotongan tarif impor perikanan dengan perubahan (efek) nilai surplus produsennya. Pada pemotongan tarif impor perikanan sebesar $20 \%$ (skenario1), $40 \%$ (skenario-2)dan 60\% (skenario-3) ternyata tidak memberikan efek (perubahan) surplus produsennya. Sementara pada potongan tarif impor perikanan sebesar $80 \%$ (skenario-4) dan sebesar 100\% (skenario-5) terjadi peningkatan (efek) nilai surplus produsen yang semakin meningkat, yaitu dari sebesar US\$ 40,437 ribu (pada skenario-4) menjadi sebesar sebesar US\$ 704,162 ribu (pada skenario-5).

Hubungan yang positif antara perubahan tingkat pemotongan tarif impor perikanan dengan perubahan (efek) nilai surplus produsennya tersebut (Tabel 6 dan Gambar 6 mengindikasikan bahwa sesungguhnya rencana implementasi IUSEPA dari sudut pandang kepentingan peningkatan kinerja perdagangan Indonesia adalah positif. Hal ini mengingat secara posisi Indonesia dalam hal ini sebagai negara produsen yang secara proporsional relatif mendominasi perdagagangan ekspor perikanannya ke pasar Amerika Serikat dibanding ekspor perikanan Amerika Serikat ke Indonesia.

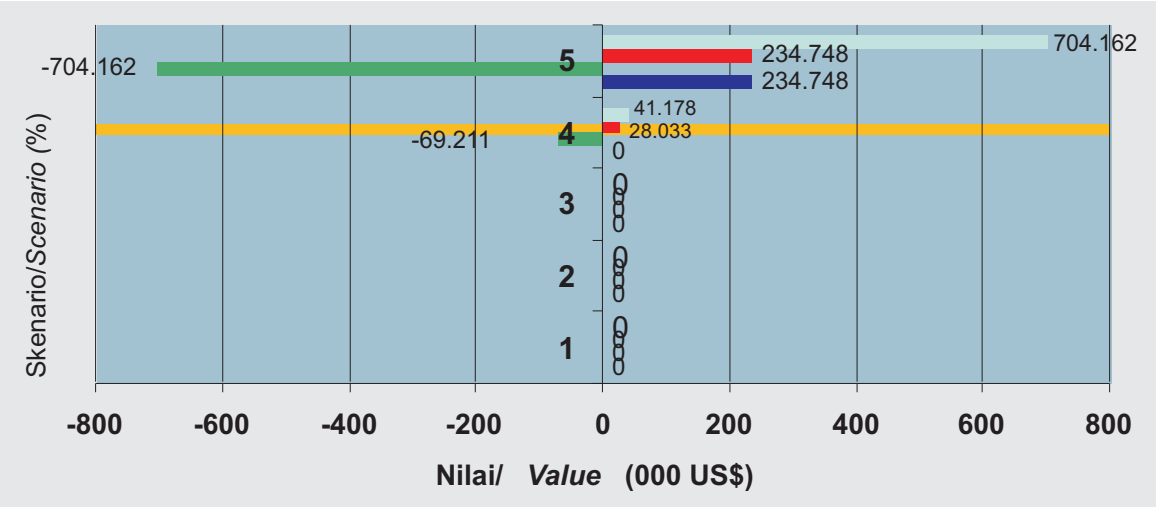

Efek Surplus Produsen/ Producer Surplus Effect

Efek Total Kesejahteraan/ Total Welfare Effect

Efek Penerimaan Tarif/ Tariff Revenue Effect

Efek Surplus Konsumen/ Consumer Surplus Effect

Gambar6. Efek Surplus Produsen dari IUSEPA menurut Skenario Pemotongan Tarif Impor, 2009

Figure 6. Producers Surplus Effect from the IUSEPA by Scenarios of Import Tariff Cutting, 2009 
을

○े

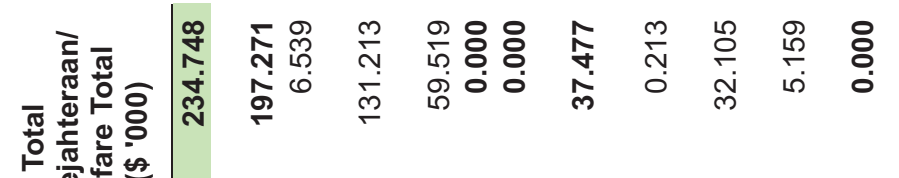

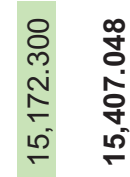

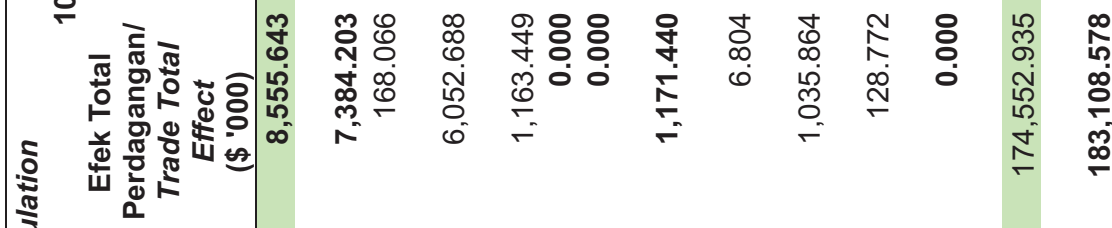

约

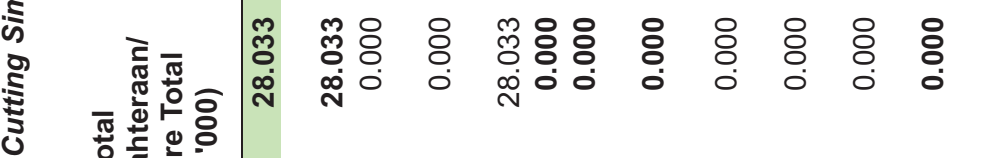

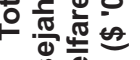

욜

ำ

产 Оे

은

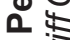

은

产

के

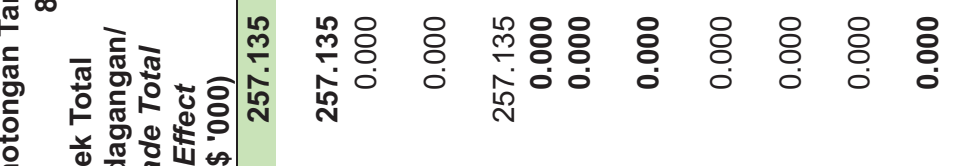

㫕인

山。․

든

ह

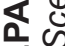

๗ ठे

马

는

\%

들

ฮิ

吉

ब.

它

\&

중

으

넌

山

ம்

ฮั

离

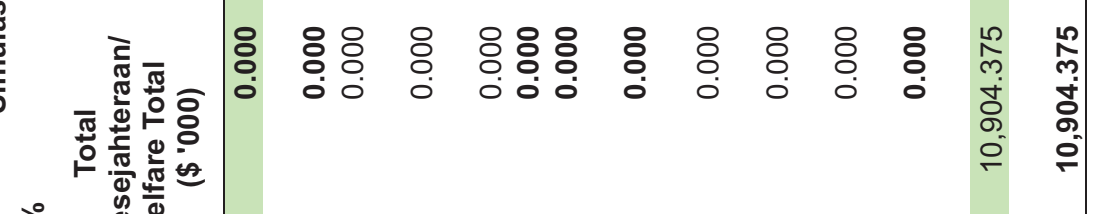

今े

กิ

은동ㅇㅇ

选㲾

山े

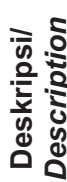

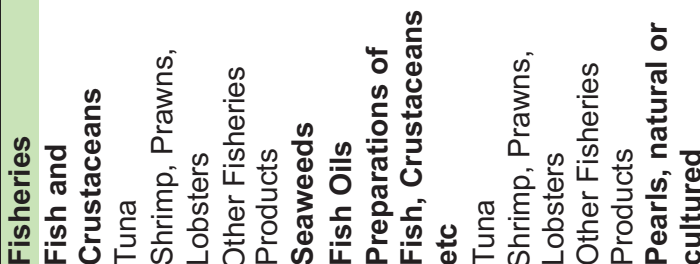

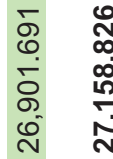

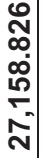

จุญ 


\section{Efek Total Kesejahteraan (Agregat Surplus) dari IUSEPA}

Efek (perubahan) total kesejahteraan dari kemungkinan dilakukannya kesepakatan kemitraan ekonomi bilateral Indonesia dengan Amerika Serikat (IUSEPA) utamanya terkait dengan perdagangan perikanan Indonesia adalah merupakan surplus agregat dari yang diperoleh dari surplus konsumen, surplus produsen dan penerimaan tarif impor pemerintah.

Dengan menggunakan alat bantu software WITS berdasarkan modul welafare effect, maka besaran perubahan efek kesejahteraan tersebut dapat dilihat sebagaimana tertera pada Tabel 6 dan Gambar 7). Dari tabel dan gambar-gambar ini dapat diketahui bahwa efek (perubahan) kesejahteraan tersebut baru terlihat pada simulasi pemotongan tarif impor perikanan sebesar $80 \%$ (skenario-4) dan simulasi pemtongan tarif impor perikanan sebesar $100 \%$ (skeneario-5), yaitu masing-masing dengan nilai sebesar US\$28,033 ribu dan sebesar US\$234.748 ribu. Sementara untuk simulasi pemotongan tarif impor perikanan sebesar 20\% (skenario-1), 40\% (skenario-2) dan $60 \%$ (skenario-3) tidak berdampak pada perubahan (efek) kesejahteraan (dengan nilai efek sebesar nol).

Bila kita perhatikan dari besaran perubahan (efek) kesejahteraan tersebut, ternyata terdapat kecenderungan semakin meningkatn jumlah pemotongan tarif impor perikanan akan berdampak terhadap meingkatnya efek total kesejahteraan (lihat Tabel 6 dan Gambar 7). Di samping itu, dari tabel dan gambar tersebut peningkatan efek kesejahteraan tersebut berhubungan dengan semakin meningkatnya efek total perdagangan (total trade effect). Hal ini mengindikasikan bahwa dengan semakin meningkatnya impor komoditas dan produk perikanan Amerika Serikat dari negara Indonesia sebagai negara mitra perdagangan bilateralnya, tidak hanya memberikan peningkatan jumlah devisa bagi negara produsennya (seperti Indonesia) akan tetapi

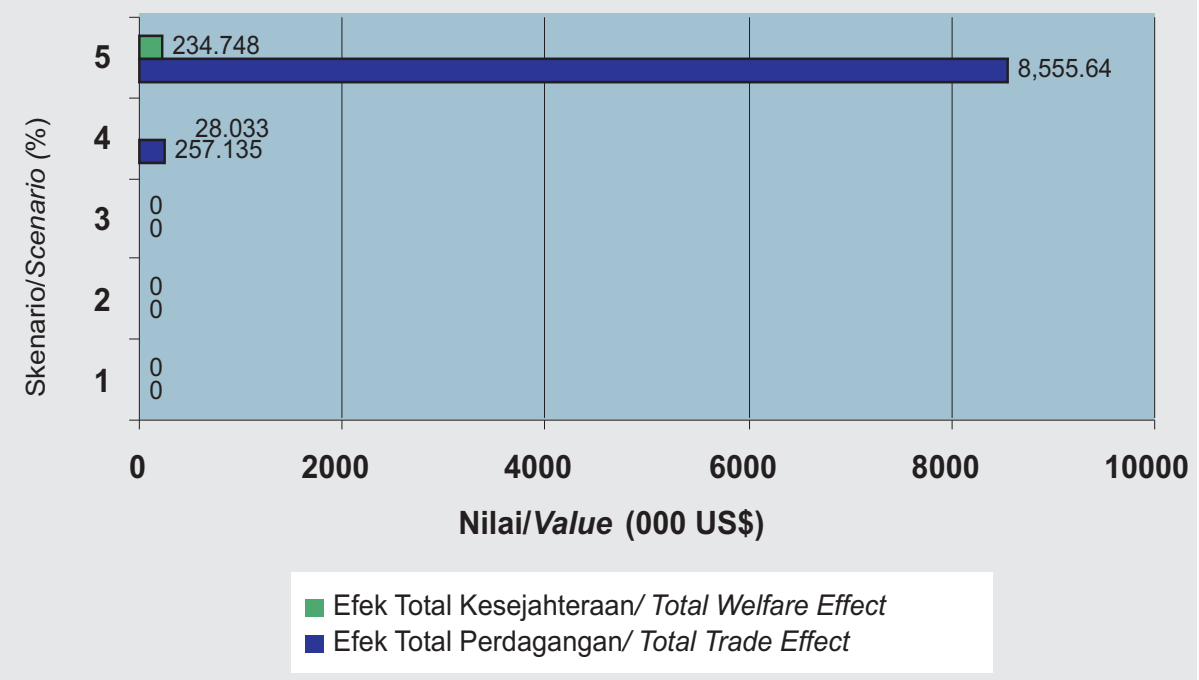

Gambar7. Efek Perdagangan Total dan Efek Kesejahteraan Total menurut Skenario Pemotongan Tarif Impor, 2009

Figure 7. Total Trade Effect and Total Welfare Effect by Screnario of Import Tariff Cutting, 2009 


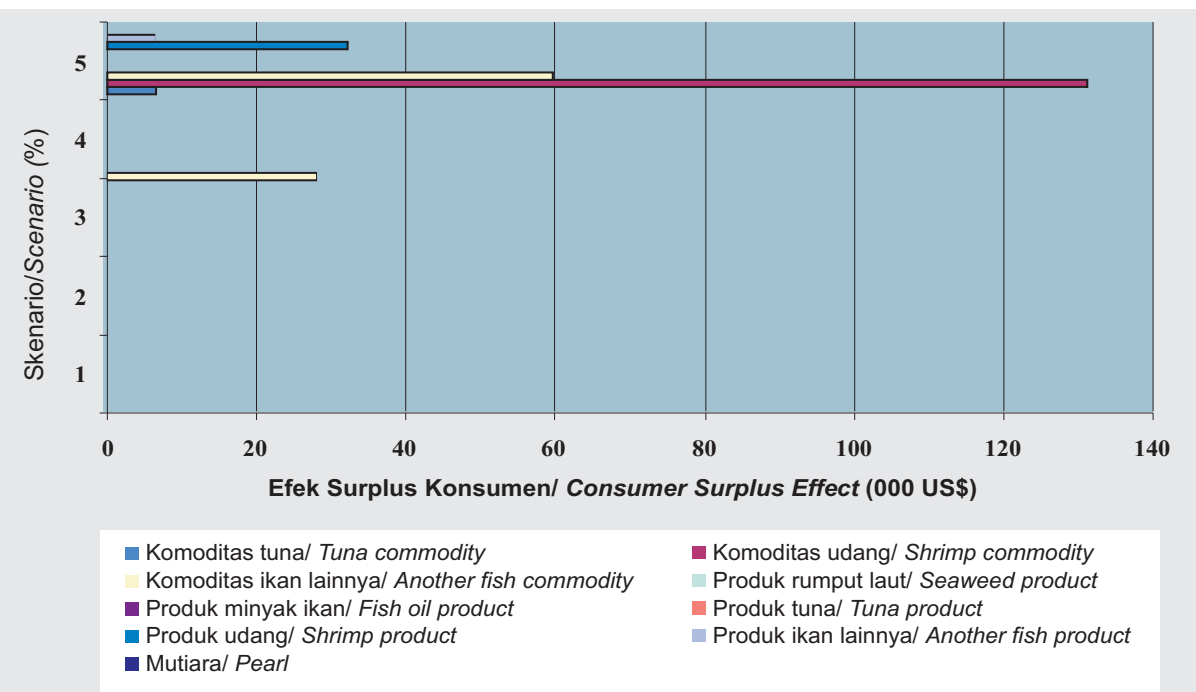

Gambar 8. Efek Kesejahteraan Total menurut Komoditas dan Produk Perikanan dari Skenario Pemotongan Tarif Impor, 2009

Figure 8. Total Welfare Effect by Fisheries Commodities and Product by Scenarios of Import Tariff Cutting, 2009

juga meningkatkan kesejahteraan secara keseluruhan dari masyarakat yang menjadi konsumennya. Sebagai contoh, pada saat efek total perdagangan sebesar US\$23,033 ribu memberikan efek total kesejahteraan sebesar US\$257,135 ribu. Sementara ketika efek total perdagangan yang semakin, yaitu sebesar US\$ 8,555.48 ribu memberikan efek total kesejahteraan lebih besar lagi yaitu sebesar US\$234,748 ribu.

Bila efek kesejahteraan tersebut dilihat menurut jenis komoditas atau produk perikanan, seperti terlihat pada Tabel 6 dan Gambar 8 terutama pada skenario-5 dapat diketahui bahwa didominasi oleh komoditas udang dan produk olahan udang yang masingmasing menyumbang efek kesejahteraan sebesar US\$ 131,213 ribu dan US\$ 59,519 ribu, dan kemudian disusul oleh komoditas tuna dan produk olahan tuna yang masingmasing menyumbang efek kesejahteraan sebesar US\$ 6,539 ribu dan US\$ 0,213 ribu. Sementara pada skenario-4, kedua komoditas dan produk olahan tersebut (udang dan tuna) belum menunjukkan kontribusi pada efek kesejahteraan, yakni sebesar nol, tetapi hanya disumbang dari komoditas ikan lainnya dengan kontribusi efek kesejahteraan sebesar US\$28,033 ribu.

\section{IV.KESIMPULAN DAN IMPLIKASI KEBIJAKAN}

\section{Kesimpulan}

1. Implementasi IUSEPA memberikan efek surplus konsumen berkaitan dengan posisi pihak Amerika Serikat sebagai negara yang mengimpor komoditas dan produk perikanannya dari Indonesia. Besaran efek surplus konsumen tersebut baru terlihat pada pemotongan tarif sebesar $100 \%$ dengan nilai peningkatan surplus konsumen sebesar US\$234,748 ribu. Sementara pada pemotoongan tarif dari sebesar 20 - 80\% belum memberikan prospek dampak terhadap perubahan (efek) surplus konsumen. Bila efek surplus konsumen tersebut dilihat menurut jenis komoditas atau produk perikanan yang diperdagangkan, ternyata diperoleh dari 
perdagangan komoditas udang dengan peningkatan (efek) surplus konsumen sebesar US\$ 131,213 ribu, dan perdagangan produk olahan udang dengan peningkatan perubahan (efek) surplus konsumen sebesar US\$ 32,105 ribu. Kemudian baru disusul oleh efek surplus konsumen yang diberikan dari perdagangan komoditas dan produk olahan tuna, masing-masing sebesar US\$ 6,539 ribu dan US\$ 0, 213.

2. Implementasi IUSEPA terkait dengan perdagangan (ekspor) perikanan memberikan prospek dampak yang positf terhadap surplus produsen. Terdapat kecenderungan meningkatnya pemotongan tarif impor (sebagai suatu instrumen) diiukuti dengan semakin meningkatnya surplus produsen, atau dengan kata lain terdapat hubungan yang positif antara perubahan tingkat pemotongan tarif impor perikanan dengan efek surplus produsennya. Pada pemotongan tarif impor sebesar 20\%, 40\% dan $60 \%$ tidak memberikan efek surplus produsennya, dan baru pada pemotongan tarif impor perikanan sebesar $80 \%$ dan $100 \%$ diperoleh nilai perubahan (efek) surplus produsen. Untuk pemotongan tarif impor sebesar $80 \%$ memberikan perubahan (efek) nilai surplus produsen sebesar US\$ 40,437 ribu dan kemudian pada pemotongan tarif impor perikanan sebesar $100 \%$ memberikan perubahan (efek) nilai surplus produsen, yaitu dengan nilai sebesar US\$704,162 ribu.

3. Implementasi IUSEPA baru akan memberikan efek terhadap perubahan total kesejahteraan (agregat welfare) pada pemotongan tarif impor perikanan sebesar $80 \%$ dan $100 \%$, yaitu masing-masing dengan nilai sebesar US\$28,033 ribu dan sebesar US\$ 234.748 ribu. Sementara pada pemotongan tarif impor perikanan sebesar $20-60 \%$ tidak memberikan efek terhadap perubahan total kesejahteraan.
Terdapat kecenderungan semakin meningkat jumlah pemotongan tarif impor perikanan akan diikuti oleh meningkatnya efek terhadap perubahan total kesejahteraan.

\section{Implikasi Kebijakan}

Implementasi IUSEPA secara agregat memberikan efek kesejahteraan yang positif khususnya bagi kinerja perdagangan sektor perikanan dan kesejahteraan masyarakat Indonesia. Dari aspek kesejahteraan (surplus konsumen, surplus produsen dan surplus agregat) sektor perikanan Indonesia dapat dipandang layak untuk diikut-sertakan dalam implementasi IUSEPA, sepanjang keikutsertaannya dilakukan dengan mekanisme pemberlakukan kebijakan pengurangan tarif (tarif reduction) atau pemotongan tarif (tarif cutting) impor berkisar antara $80 \%$ hingga $100 \%$ dari tarif bea masuk perikanan yang diberlakukan Amerika Serikat sebesar $35 \%$, atau dengan pemberlakuan tarif bea masuk (impor) berkisar antara sebesar $7 \%$ hingga $0 \%$.

Dalam rangka menegosiasikan usulan tarif menjadi $0-7 \%$, diperlukan strategi yang efektif sehingga dapat secara tepat mencapai sasaran dalam bernegosiasi dengan pihak Amerika Serikat. Hal ini karena kedua negara, Indonesia dan Amerika Serikat berada dalam posisi yang tidak seimbang dimana Indonesia akan menempatkan diri dalam posisi defensif, dengan strategi: (a) Melakukan perhitungan yang mencoba untuk "mengalah" pada sektor tertentu dan berusaha mendapatkan keuntungan dari sektor perikanan, dan antisipasi komplementari fasilitasi bagi peningkatan dalam capacity-building dan perluasan usaha perikanan nasional; dan (b) Memperkuat koordinasi antar institusi yang selama ini dinilai lemah, yaitu dengan lebih sering melakukan pertemuan koordinasi dan melarang setiap institusi yang tekait memberikan komitmen tanpa sepengetahuan chiefnegotiator. 


\section{DAFTAR PUSTAKA}

Christos, F. and Failler, P. 2004. Policy Analysis for Fisheries: A Dinamic CGE Approach. Paper Presented at the International Conference Input-Output and General Equilibrium Data, Modeling and Policy Analysis, Brussels, 2-4 September, 2004.

Bacchetta, M. and Jammes, O. 2004. World Integrated Trade Solution (WITS). Presentation GTAP Conference. Trade Department, the World Bank., Washington D.C.

Bhagwati, J. N. 1991. The World Trading System at Risk. Harvester Wheatsheaf, Hemel Hempstead.

Brent, R.J. 1997. Applied Cost-Benefit Analysis. Edward Elger., Cheltenham.

Baldwin, R. 1995. A Domino Theory of Regionalism. Expanding Membership of the European Union, Cambridge University Press., Cambridge.

Großmann, G. dan Buse, E.H. 1996. The Politics of Free Trade Agreements, American Economic Review, LXXXV,: 667-690; Levy, P. 1997. A Political Economic Analysis of Free Trade Agreements. American Economic Review, LXXXVII, : 506-519.
Krugman, R.P.. 1991. Ekonomi Internasional Teori dan Kebijakan. PT. RajaGrafindo Persada., Jakarta.

Pratomo, W. 2007. Teori Kerjasama Perdagangan Internasional dalam Buku: Kerjasama Perdagangan Internasional: Peluang dan Tantangan bagi Indonesia. Editor : Syamsul Arifin, Dian Ediana dan Charles P.R. Joseph. Gramedia., Jakarta. Setiawati, H. dan Amier, G. 2004. Kerjasama Perdagangan Multilateral, dalam Buku: Kerja $s$ a $m$ a $P$ erdag $n g$ a $n$ Internasional:Peluang dan Tantangan bagi Indonesia. Editor: Arifin, S., Rae, D.D., dan Joseph, C.P.R. Gramedia., Jakarta.

Suranovic. S. 1997. International Trade Theory and Policy Text Book. George Washington University. dalam Pratomo, W. 2004. Teori Kerjasama Perdagangan Internasional, dalam Buku: Kerjasama Perdagngan Internasional: Peluang dan Tantangan bagi Indonesia. Editor: Arifin, S., Rae, D.D., dan Joseph, C.P.R. Gramedia., Jakarta.

Viner. 1990. The Customs Union Issue. Carnegie Endowment for International Peace., New York. 